\title{
Post-Mining Vegetation Database Eastern Germany
}

\author{
Gerd Jünger, Annett Baasch, Anita Kirmer, Antje Lorenz \& Sabine Tischew
}

\begin{abstract}
In eastern Germany, surface mining of lignite led to the destruction of entire landscapes and the interlinked ecosystems. After the German reunification in 1990, the majority of mining sites across eastern Germany were closed. During the last two decades, post-mining landscapes offered a unique chance to observe primary succession and have been subject to scientific research on spontaneous and assisted site recovery of heavily disturbed sites. Beginning in 1993, several research projects in surface-mined land have collected comprehensive vegetation data. The main objective was to gain knowledge about spatial and temporal processes of vegetation recovery and to derive guidelines for further restoration planning. Up to now, the post-mining vegetation database contains more than 5,000 vegetation relevés that have been compiled over the last two decades. The majority of the plots investigated are located in the post-mining landscapes of the Central German lignite mining district. Also, relevés were collected in the Lusatian mining region. Some of the plots were regularly revisited. Usually, the metadata of each relevé includes information on plot location (GPS coordinates) and abiotic conditions (exposition, $\mathrm{pH}$ and other soil attributes). This report describes the available content in the Post-Mining Vegetation Database Eastern Germany (GIVD ID EU-DE-023).
\end{abstract}

Keywords: post-mining landscape; primary succession; restoration; vegetation dynamics.

\section{Post-Mining Vegetation Database Eastern Germany}

Scope: The post-mining vegetation database contains vegetation relevés that have been compiled over the last two decades in the post-mining landscapes of Eastern Germany.

Status: completed and continuing

Period: 1994-2009

Database manager(s): Gerd Jünger (g.juenger@loel.hs-anhalt.de); Annett Baasch (a.baasch@loel.hs-anhalt.de); Anita Kirmer (a.kirmer@loel.hsanhalt.de)

Owner: Anhalt University of Applied Sciences, Department for Nature Conservation and Landscape Planning, Working Group Prof. S. Tischew Web address: [NA]

Availability: according to a specific agreement

Database format(s): MS Access

Online upload: no

Online search: no

Publication: [NA]

Plot type(s): normal plots; time series

Non-overlapping plots: 3,247

Export format(s): MS Access, Excel, CSV file, MySQL

Total plot observations: 5,194

Plot-size range: $1-10,000 \mathrm{~m}^{2}$

Countries: DE: $100.0 \%$

Forest: 29\% — Non-forest: aquatic: 0; semi-aquatic: 11\%; arctic-alpine: 0; natural: 0; semi-natural: 45\%; anthropogenic: $8 \%$

Guilds: all vascular plants: $100 \%$

Environmental data: slope aspect: $51 \%$; slope inclination: $51 \%$; microrelief: $29 \%$; soil depth: $98 \%$; surface cover other than plants (open soil, litter, bare rock etc.): $86 \%$; soil pH: $65 \%$

Performance measure(s): cover: $100 \%$

Geographic localisation: GPS coordinates (precision $25 \mathrm{~m}$ or less): $73 \%$; small grid (not coarser than $10 \mathrm{~km}$ ): $27 \%$

Sampling periods: $1990-1999: 55.0 \% ; 2000-2009: 45.0 \%$

Information as of 2012-07-12; further details and future updates available from http://www.givd.info/ID/EU-DE-023

Gerd Jünger* (g.juenger@loel.hs-anhalt.de), Annett Baasch (a.baasch@loel.hs-anhalt.de), Anita Kirmer (a.kirmer@loel.hs-anhalt.de), Antje Lorenz (a.lorenz@ loel.hs-anhalt.de), Sabine Tischew (s.tischew@loel.hs-anhalt.de)

Department for Nature Conservation and Landscape Planning, Anhalt University of Applied Sciences, Strenzfelder Allee 28, D-06406 Bernburg, GERMANY

*Corresponding author 